\title{
BROMHEAD RARE BIRD RECORDS
}

CAROL F. BJORKLUND, 3634 McCallum Avenue, Regina, Saskatchewan. S4S 0S5

The following records are all those of the author unless specified in the text. If not otherwise noted, the observations took place in the farmyard of Lorne and Carol Bjorklund, 2 miles north of Bromhead, Saskatchewan, at SW15-3-13W2nd.

Bromhead is situated in the extreme south of the province about 13 miles north of the Saskatchewan - North Dakota boundary and just a few miles from the eastern edge of the Missouri Coteau. The land is flat and open, intensively cultivated, with most sloughs drained and ploughed. Farm shelterbelts offer most of the habitat suitable for birds. Long Creek runs about 2 miles south of Bromhead and is thought to be the corridor for movement of some of the birds in this area.

\section{CINNAMON TEAL}

A pair of Cinnamon Teal was first seen on 30 May 1979 in a water-filled ditch adjoining a marshy slough a half mile east of Bromhead. The pair was observed twice daily, morning and afternoon. Observations were facilitated since the site was directly beside a railroad track adjacent to the road. The teal became accustomed to the traffic and did not flush. Observations ceased at the end of June. Nesting was not confirmed.

The Cinnamon Teal is fairly common in extreme southwestern Saskatchewan and wide-ranging to Kindersley, Saskatoon, Last Mountain Lake and Moose Jaw. There are two breeding records for the province, a "pair evidently breeding" 17 mi. southwest of Moose Jaw in 1923 and a "male, possibly paired" seen at Last Mountain Lake Wildlife Management

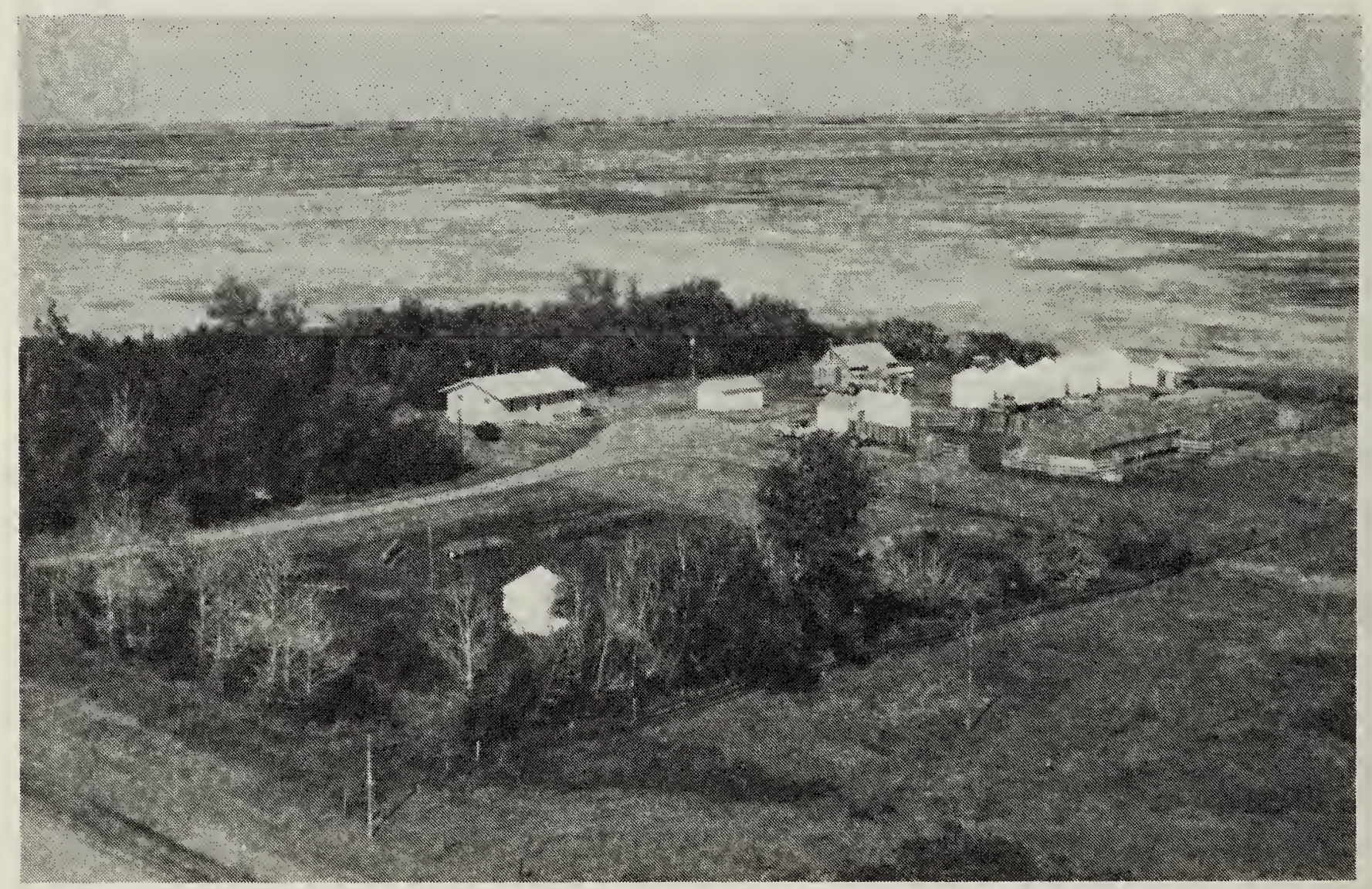

The farmyard of Lorne and Carol Bjorklund in 1976 


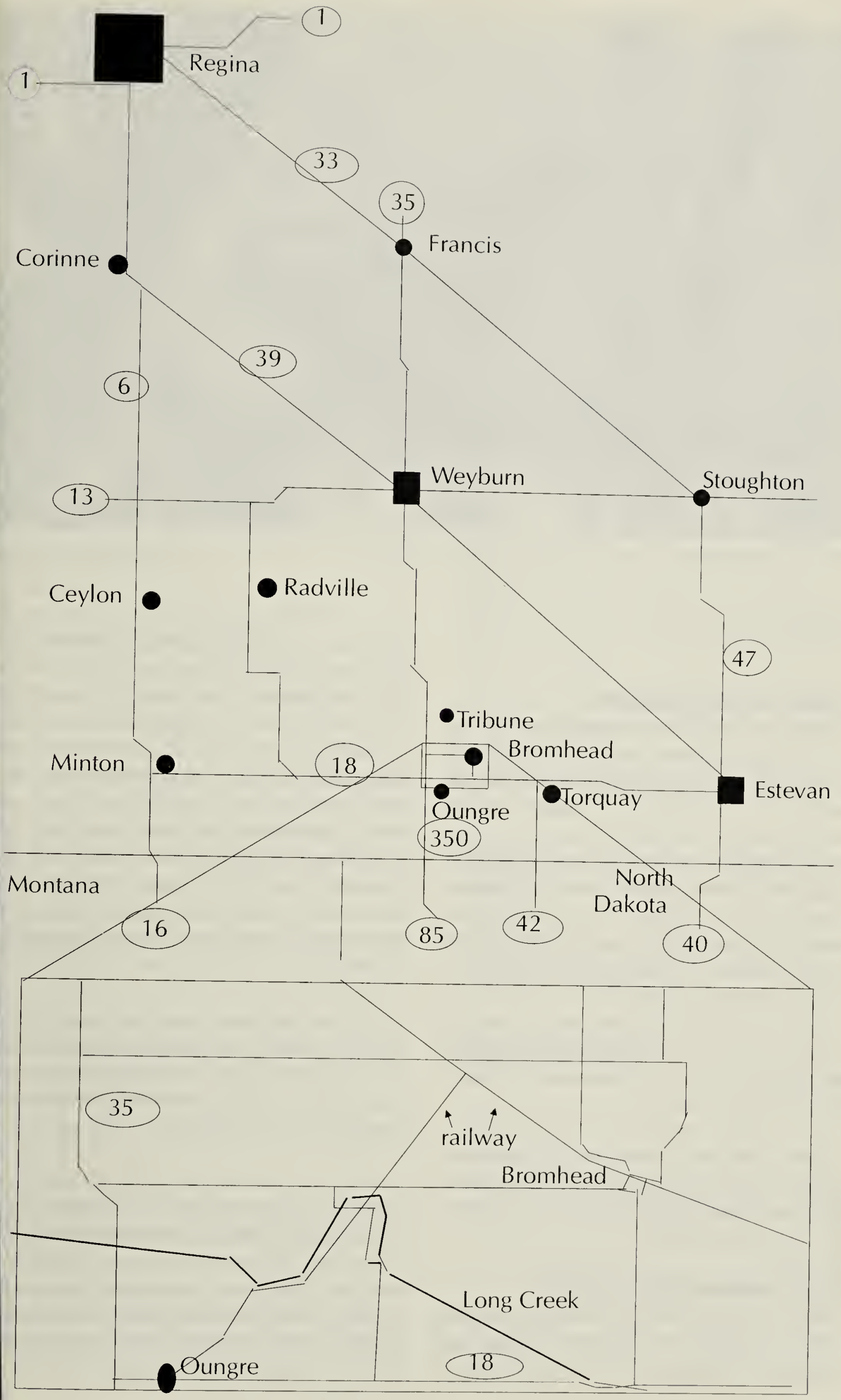

(4). December 1990 


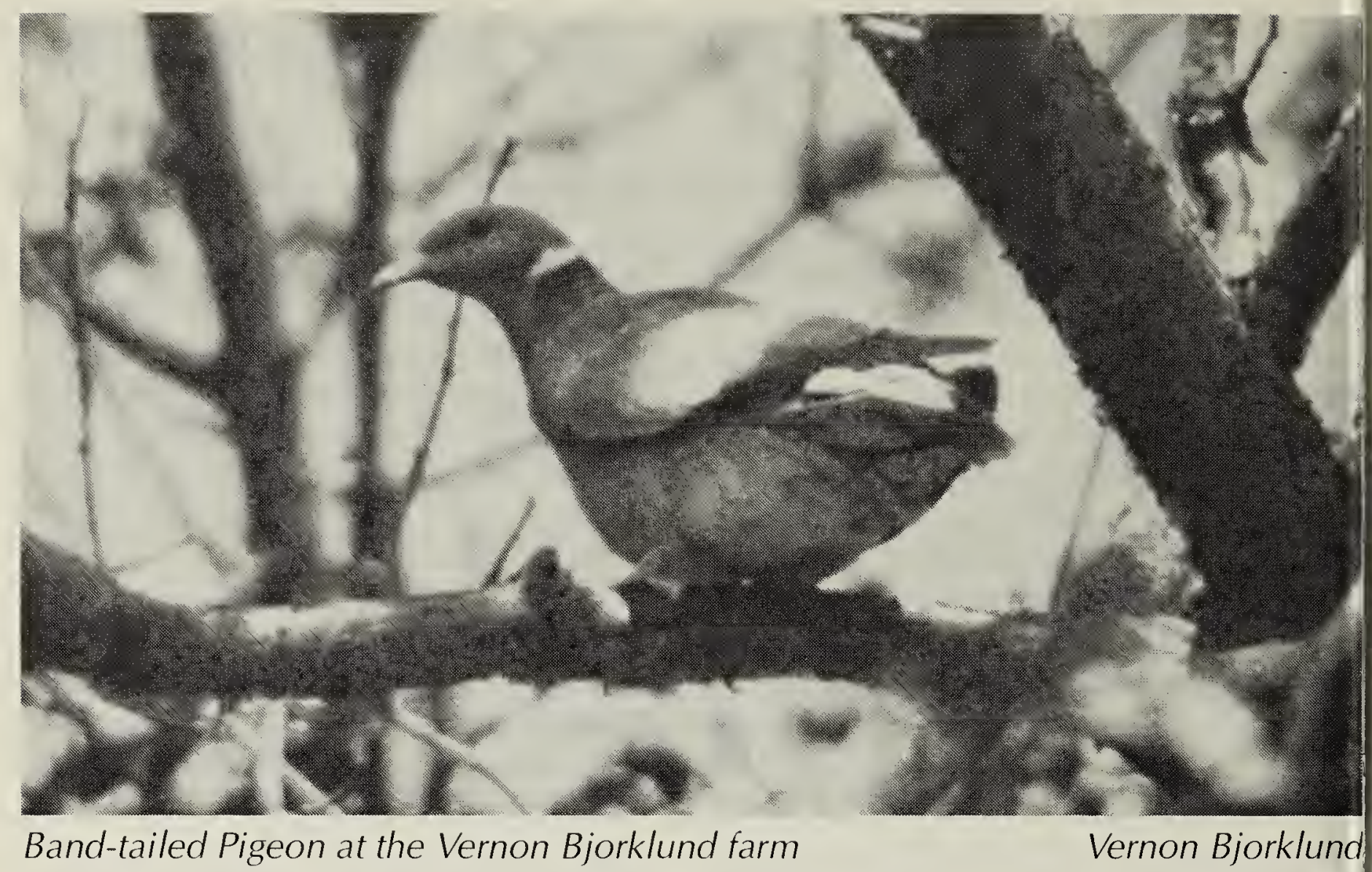

Unit by Wayne Harris from 4-27 May 1983."

\section{BAND-TAILED PIGEON}

On 3 July 1984, a strange pigeon flew by Vernon Bjorklund as he worked in his farmyard north of Bromhead. The pigeon landed in an apple tree nearby and he observed it briefly before taking photographs of the bird. The bird remained in the yard only a short time and was not seen again. The photographs show the identifying marks of the Bandtailed Pigeon: yellow bill tipped with black, yellow legs and feet, narrow white band on the back of the neck and the broadly banded tail. This is the first documented record of the Band-tailed Pigeon for Saskatchewan.

There are nine other records for Saskatchewan, including another documented sighting from Weyburn 24 August to 5 September 1984.

\section{YELLOW-BILLED CUCKOO}

This species was first seen 15 August 1982, although its raucous croaks had been heard previously during the sum- mer. The bird was perched quietly on an open branch 30 feet away. It had a lighi eye ring and a bi-coloured bill - the upper mandible dark, and the lower yellow. There were reddish-brown patches in the wings; the undertail pattern of black and white showed much more contrasi than that of the Black-billed Cuckoos which nested in the yard. After this bird had been identified as a Yellow-billed Cuckoo, Peterson's Field Guide to Bird Songs was used to confirm the identity of the songs that had been heard through the summer.

On at least two other occasions that summer, two of these cuckoos were seen flying together. It is not known if nesting took place. A Yellow-billed Cuckoo was heard on 12 June 1983.

There is one record of this species from Estevan, 8 June 1974, by T.M. Beveridge. One unpublished record exists from the Cypress Hills area where, in 1979, Wayne Harris heard and saw this species at the Wilkes Parsonage ranch on Battle Creek. (pers. comm.) Paul Chytyk hearch a Yellow-billed Cuckoo sing briefly ab 


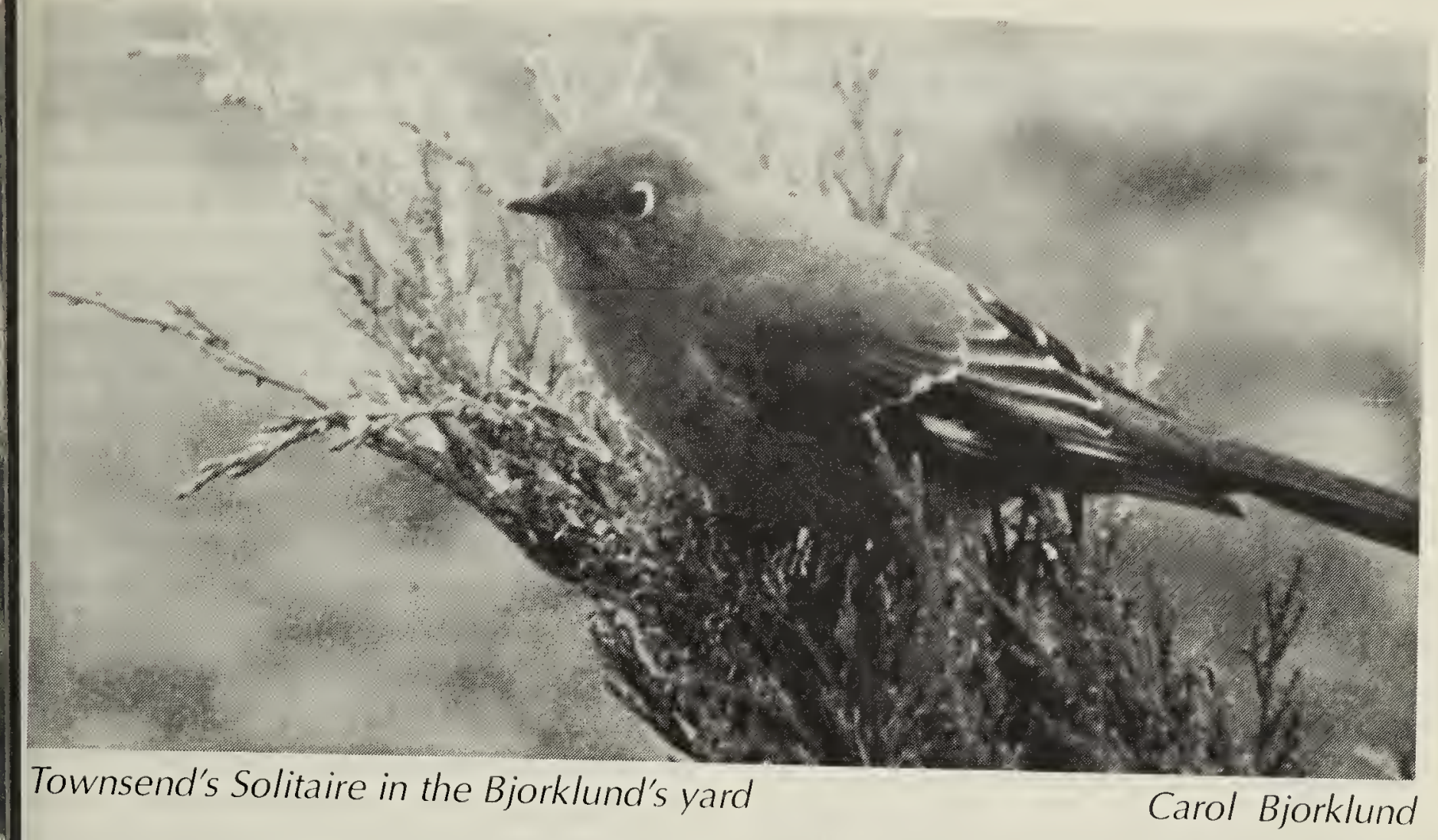

Roche Percee Regional Park, 22 July 1988 (pers. comm.).

\section{TOWNSEND'S SOLITAIRE}

There are two records of Townsend's Solitaire at Bromhead. Photographs were taken of one of the birds (see figure).

In late afternoon, 11 April 1983, a ownsend's Solitaire appeared in the yard nd fed on the berries of the juniper under he house window. It was gray all over, with yellow-brown patches in the wings nd a bit of white edging on some wing athers. The tail was long, with white uter feathers noticeable in flight. There as a white eye ring. The bird hunted by itting in a tree until spotting prey, upon hich it flew down, caught and ate the $\mathrm{em}$ and then returned to the tree. Two hotos were taken when the bird returned the juniper near dusk. It was not seen sain.

The second record is from the fall of 984 when another solitaire came on 22 ptember and was seen almost every y until 19 October. This bird was very iwary and followed us around the yard, metimes coming from a hidden place have a look at Lorne as he worked

outside. The bird spent a considerable amount of time sitting on the south porch, presumably to take advantage of the heat emanating from the house and the reflected sunshine from the wall. It ate cotoneaster berries and juniper berries. Not many insects could have been available since the weather was very cool, but the solitaire ate those it could find.

Townsend's Solitaire is a rare, erratic wanderer in southern Saskatchewan, mostly in spring, fall and winter. There is one breeding record from the Cypress Hills, where a territorial pair and one non-flying fledgling were found in July 1979 by Wayne Harris (pers. comm.).

\section{SAGE THRASHER}

On the morning of 21 June 1985, a Sage Thrasher was observed for at least 10 minutes as it ran quickly about on the driveway by the house, feeding on insects. Its general shape was long and slim, with a long, thin, slightly decurved bill. The bill and legs were dark; wing bars were not noticed. Upperparts were dull grayish. Underparts were heavily streaked with dark brown on an off-white background. The tail was long, with whitish spots on the terminal underside. 
The bird was seen again at 7:30 p.m. when it was running around in the grass in the barnyard, eating insects. No photographs were taken.

The Sage Thrasher is irregular to rare in southwestern Saskatchewan and occasionally breeds there. There are two other records outside the southwest of the province: 23 June 1963, one bird at Porter Lake; in June 1986, a singing male in the Big Muddy."

\section{FIELD SPARROW}

Field Sparrows were recorded several times in our yard, 2 mi. $\mathrm{n}$ of Bromhead. There are photographs from September 1980 and 8 September 1984.

A journal entry for 7 September 1985 contains a description of three Field Sparrows feeding beside the house: reddishbrown crown, pink bill, gray face, plain breast and underparts grayish-white, streaked upperparts but plain rump, notched tail with lighter-coloured edges, two white wingbars, sides slightly buffy, legs pink, white eye ring. These birds were very skittish and preferred to feed under or around bushes or in the longer grass. Two Field Sparrows were seen the next day and two on 9 September. There are six other records of the Field Sparrow in Saskatchewan, two of which are in the southeast, one in Weyburn ${ }^{8}$ and one at Estevan (A.R. Smith, unpubl. data).

\section{GREAT-TAILED GRACKLE}

This species was not separate from the Boat-tailed Grackle at the time it was seen in 1979; however, based on my observations and later comparison of descriptions of the "split" species, it is assumed the species that I saw was the Great-tailed Grackle. Great-tailed Grackles can be differentiated from Boat-tailed Grackles by the former's flat rather than rounded crown, bright yellow eyes as distinguished from the brown or dull yellowish eyes of the Boat-tailed Grackle, and by the longer and broader tail.
The Common Grackle is a common breeding bird of this area. Although size is relative, the difference between Common and Great-tailed grackles is so great, 18 in. for a male Great-tailed as compared to approximately 12 in. for a male Common, that it was obvious at once that the bird was different. There are differences in color between the two species as well. In the male Common Grackle the bluish-purple gloss of the head and neck is abruptly cut off from the iridescence of the rest of the plumage. In the male Great tailed Grackle the purplish gloss includes the head, neck, back and underparts. The tail of a the Great-tailed is relatively much longer than the tail of the Common Grackle. Eyes of both species are yellow but those of the Common Grackle are a paler yellow. Female Common Grackles are smaller and duller in color than males. The female Great-tailed Grackles are also smaller than the males but entirely dif ferent in color, being plumaged in shades of brown.

At 1:00 p.m. 14 May 1979, one male Great-tailed Grackle landed on the drive directly in front of the house and was observed carefully at close quarters for about a half hour. The bird was as long as a crow but much slimmer, with a flattish crown and yellow eyes. It was black all over, with iridescence on the head and body. Its tail was V-shaped and extremely long, dragging on the ground as the bird walked, and blowing in the wind. The grackle gave many different kinds of loud calls: squeaky, hoarse, vibrating and gurgling, short, high-pitched squeaks, loud clicks. The presence of this loud and bossy bird resulted in an uproar amongst all the other birds of the yard. After a time, the grackle flew to a spruce and examined an old crow's nest. Another Great-tailed Grackle joined it there. The two then left.

At the same time, a group of 5 or 6 Great-tailed Grackles was seen in Bromhead, $2 \mathrm{mi}$. south of our farm. They stayed 
for nearly a week and were seen by other observers besides Lorne and Carol Bjorklund. Though initially people in Bromhead were pleased to see these new birds, the grackles quickly wore out their welcome because of their habit of harrassing and terrifying the resident bird population. After these few days, the grackles disappeared as mysteriously as they had come.

There are no other records for this species in Saskatchewan. For Canada, there is one other record, that of a female photographed at Cape St. James, Queen Charlotte Islands in May 1979. 'There are two Canadian sight records of the Boattailed Grackle, single birds on Sable Island, 7 May 1968 and at Glace Bay, 5 August 1969.

\section{ORCHARD ORIOLE}

This species was first noted in our area in May of 1977 when a singing first-year male was observed in a farmyard west of Bromhead. The next record was 20 June 1979 , again a singing first-year male, this time at a farm near Colgate. In 1980 two irst-year males inhabited our own yard and proved themselves prodigious ingers, as well as good scrappers in teritorial disputes. The next year we noted ne adult male. From these beginnings, he Orchard Oriole has spread so that almost every shelterbelt in the area hosts hem. Our farmyard supported three pairs it their peak population, but numbers vere drastically reduced, and those on ome farms disappeared, during the sumners of heavy spraying for grasshoppers.

Most other records of the Orchard Priole in Saskatchewan have occurred ince 1980, the species being now well stablished, having first bred in the exreme southeast of the province and radually dispersed west and north.

Records previous to 1980 include a rst-year male at Regina in June 1972, a mily group at Ft. Qu'Appelle in June and July of 1974, an adult male near Tantallon 8 June 1976, and a sighting at Indian Head on the same day in 1976. There was also a sighting in May 1979 at Regina of a first-year male.

\section{ROSY FINCH}

Two Gray-crowned Rosy Finches were photographed by Lorne Bjorklund in the yard on 4 November 1983. They were seen for a short time only on that day. In the photographs, the black forehead, gray back of head, brown upper back and rosy brown of the lower body can all be seen.

Though this species is seen regularly in southwestern Saskatchewan, no other records were found for the southeast of the province.

' ADAM, C.I.G. and R. KREBA 1985. First documented record of the Band-tailed Pigeon in Saskatchewan. Blue Jay 43:4041.

2 BELCHER, M. 1980. Birds of Regina. SNHS Special Publ. \#12. 151 pp.

3 BEVERIDGE, T.M. 1974. Northern Great Plains region. Am. Birds 28(5):917.

${ }^{4}$ CALLIN, E.M. 1980. Birds of the Qu'Appelle. SNHS Special Publ. \#13. 168 pp.

${ }^{5}$ GODFREY, W.E. 1986. The Birds of Canada, revised ed. Natl. Mus. of Natural Sciences, Ottawa. 595 pp.

${ }^{6}$ GOLLOP, J.B. and M.A. GOLLOP 1963. Some 1963 bird records for the Saskatoon district. Blue Jay 22:9.

GOLLOP, J.B. 1986. Prairie Provinces region. Am. Birds 40:1218-1219.

${ }^{8}$ GOLLOP, J.B. 1988 . Prairie Provinces region. Am. Birds 42:1304-1305.

${ }^{9}$ HARRIS, W.C. 1983. Prairie Provinces region. Am. Birds 37(5):883.

10 MITCHELL, H.H. 1924. Birds of Saskatchewan. Can. Field-Nat. 38:101-118. 